\title{
Lipid Synthesis and Reproduction in the Polar Shrimp Chorismus antarcticus
}

\author{
Andrew Clarke \\ British Antarctic Survey, NERC, High Cross, Madingley Road, Cambridge CB3 OET, England
}

\begin{abstract}
Chorismus antarcticus (Pfeffer, 1887) is a small benthic hippolytid shrimp which breeds seasonally, producing a batch of large, lipid-rich eggs that are brooded over winter by the female, and hatch the following spring. Ovary size increased linearly during the 2 mo prior to spawning, and lipid accumulated at a rate of $3.7 \mathrm{mg}$ per $10 \mathrm{~d}$ in a female shrimp of $2 \mathrm{~g}$ fresh weight. Hepatopancreas reserves were insufficient to account for all the material necessary for vitellogenesis, and the hepatopancreas remained constant in size until the last few weeks of ovarian maturation when lipid was used at a rate of $2.2 \mathrm{mg}$ per $10 \mathrm{~d}$. Total lipid synthesis was measured by incubation of isolated whole ovary or hepatopancreas in crustacean saline containing tritiated water. The observed tritium incorporations showed clearly that vitellogenesis in summer was accompanied by a small increase in de novo synthesis, estimated at about $0.197 \mathrm{mg}$ per $10 \mathrm{~d}$ for a $2 \mathrm{~g}$ shrimp. Thus only a small fraction of the lipid required for eggs is provided by an increase in de novo synthesis. Much of the egg lipid, including all the essential $\omega 3$ and $\omega 6$ polyenoic fatty acids, thus comes directly from the food. This is a strategy different from planktonic euphausiids and some starfish, where vitellogenesis is fuelled largely by utilisation of previously stored reserves. However, food availability for $C$. antarcticus at South Georgia in summer is sufficient to provide for both somatic growth and complete ovarian maturation within 6 mo before spawning in late summer. There is thus no need for large lipid stores, or substantial lipid synthesis, and the hepatopancreas acts as a metabolic centre than a concentration of reserves.
\end{abstract}

\section{INTRODUCTION}

Many polar marine invertebrates produce large, yolk-rich eggs (Thorson, 1950). It is not clear, however, to what extent this imposes a strain on the maturing female, since gonad maturation is usually slow and in many cases annual individual reproductive effort is less than in related warmer water species (Clarke, 1979 a). It is not known what proportion of the lipid in the eggs is derived directly from ingested food and what proportion is mobilised from previously stored reserves, by utilisation of pre-formed lipid or synthesis de novo from non-lipid precursors. The relatively high levels of monoenoic fatty acids in the eggs of some crustaceans suggest some de novo synthesis (Morris, 1973; Clarke, 1977b, 1979b), but the large amounts of polyenoic fatty acids such as $20: 5 \omega 3$ and $22: 6 \omega 3$ also mean that much of the egg lipid must come directly from the food.

In this study, the rate of total lipid synthesis was estimated in isolated tissues from the benthic shrimp Chorismus antarcticus (Pfeffer, 1887), and compared with the rate of accumulation of lipid in the ovaries of wild shrimps.

\section{MATERIALS AND METHODS}

Shrimps were sampled with a $1 \mathrm{~m}$ Agassiz trawl from varied substrates at depths of 25 to $80 \mathrm{~m}$ in King Edward Cove, South Georgia during the austral summer $1979 / 80$. The sampling area and general biology of Chorismus antarcticus have been described elsewhere (Clarke and Lakhani, 1979; Clarke, 1979a). Specimens in good physiological condition were maintained in seawater aquaria at 2 to $4{ }^{\circ} \mathrm{C}$ for up to $4 \mathrm{~h}$ before measurement of lipid synthesis. The fresh weight, carapace length, and the fresh weight of the ovary and hepatopancreas were measured on all female shrimps. Ovary and hepatopancreas indices were calculated as:

$100 \times($ fresh wt organ)

(fresh weight shrimp - fresh weight ovary).

This measure avoids a decrease in hepatopancreas 
index caused merely by an increase in ovary size rather than changes in the hepatopancreas itself (Clarke, $1977 \mathrm{a}$ ). C. antarcticus is a widely distributed circumpolar species found at depths of 15 to $915 \mathrm{~m}$ (Zarenkov, 1970); there was no evidence that either fecundity or rate of ovary maturation varied with depth or substrate within the sampling area of this study (Clarke, unpubl.).

\section{Lipid Synthesis Assay}

Lipid synthesis in vitro was measured for a total of 27 male and 26 maturing female shrimps on 5 dates between Dec 28th and Jan 14th, and for 13 ovigerous females on April 3rd. Lipid synthesis rates were measured by monitoring uptake of protons from crustacean saline, using tritium as tracer. This technique estimates total lipid synthesis, whereas assay by uptake of ${ }^{1.4} \mathrm{C}$-labelled glucose or ${ }^{14} \mathrm{C}$-labelled acetate measures only a fraction of the total synthesis (Jungas, 1968). Double strength saline was diluted $1+1$ with tritiated water to a final concentration of $394 \mathrm{mM} \mathrm{Na}^{+}$, $7.7 \mathrm{mM} \mathrm{K}^{+}, \quad 12.7 \mathrm{mM} \mathrm{Ca}^{2+}, \quad 12.6 \mathrm{mM} \mathrm{Mg}^{2+}$, $447 \mathrm{mM} \mathrm{Cl}^{-}, 2.6 \mathrm{mM} \mathrm{SO}_{4}{ }^{2-}, 10 \mathrm{mM}$ alanine, $10 \mathrm{mM}$ glucose, $10 \mathrm{mM} \mathrm{Na}$ acetate and $0.65 \mathrm{mCi} / \mathrm{ml}^{3} \mathrm{H}_{2} \mathrm{O}$. Isolated hepatopancreas or ovaries were incubated in this saline for $5 \mathrm{~h}$ at $2^{\circ} \mathrm{C}$ in a shaking water bath; control tubes contained tissue in ( $x 1$ ) saline but no tritium. Experiments were stopped by extracting the tissue in ice-cold de-gassed methanol-chloroform (Bligh and Dyer, 1959). Chloroform extracts were then thoroughly washed to remove tritiated water and returned to $\mathrm{UK}$ for counting, in chloroform containing $0.01 \% \mathrm{BHT}$, sealed under $\mathrm{N}_{2}$ and stored at $-50^{\circ} \mathrm{C}$.

In half the samples the total lipid extract was counted. In the remainder the lipid was made up to $2 \mathrm{ml}$ with chloroform; $1 \mathrm{ml}$ was counted as total lipid and $1 \mathrm{ml}$ was separated into polar lipid (PL) and triacylglycerol (TAG) fractions by TLC before counting.

A small number of male hepatopancreas were incubated in $1 \mathrm{ml}(\times 1)$ saline containing $50 \mu \mathrm{Ci}^{-1}$ ml[NA U- $\left.{ }^{14} \mathrm{C}\right]$ acetate but no ${ }^{3} \mathrm{H}_{2} \mathrm{O}$. Lipid was extracted as previously and the total Iipid sample adsorbed onto a TLC plate. These were planchet counted in Antarctica with a small portable Geiger counter, and recounted in UK. Although incorporation of ${ }^{14} \mathrm{C}$ into lipid from $\mathrm{Na}\left[\mathrm{U}-{ }^{14} \mathrm{C}\right]$ acetate measures only part of the total lipid synthesis, these experiments allowed linearity of uptake to be established in Antarctica before the main experiments were performed.

All samples were counted on a Nuclear-Chicago Mk III scintillation counter with automatic correction for background and quench via an external ${ }^{133} \mathrm{Ba}$ standard. Lipid samples were blown dry of solvent with $\mathrm{N}_{2}$ and counted in $14 \mathrm{ml}$ Picofluor 15 with efficiencies of $94 \%$ for ${ }^{14} \mathrm{C}$ and $45 \%$ for ${ }^{3} \mathrm{H}$. Lipid samples adsorbed onto silica gel were counted in $3 \mathrm{ml}$ water plus $10 \mathrm{ml}$ Instagel with efficiencies of $90 \%$ for ${ }^{14} \mathrm{C}$ and $30 \%$ for ${ }^{3} \mathrm{H}$.

The calculation of absolute rates of lipid synthesis from tritium incorporation involves a number of assumptions and approximations. These are:

(1) Diffusion of ${ }^{3} \mathrm{H}_{2} \mathrm{O}$ into the cytoplasm immediately surrounding the synthetic machinery is very rapid compared with the time scale of the experiment; thus the specific activity of the incubation medium accurately reflects that within the cytoplasm, and the slope of Fig. 5 represents synthesis rather than diffusion.

(2) All the fatty acid synthesised is palmitic acid, 16:0, containing on average $13.3 \mathrm{mg}$ atoms ${ }^{1} \mathrm{H}$ or ${ }^{3} \mathrm{H}$ from the incubation medium per mmol 16:0 (Windmueller and Spaeth, 1966).

(3) This fatty acid is all converted immediately to glycerol tripalmitate (mol. wt 807.35) containing 3 newly synthesised 16:0 chains and no ${ }^{3} \mathrm{H}$ in the glycerol moeity (that is, glycerol synthesis for triacylglycerol and synthesis of phospholipid are assumed to be zero).

(4) ${ }^{3} \mathrm{H}$ atoms were equally divided between $\mathrm{H}^{+}$and $\mathrm{OH}^{-}$; water of specific activity $D$ dpm per mmol water thus contained $0.5 \times D \mathrm{dpm}$ per $\mathrm{mg}$ atom $\mathrm{H}^{+}$.

(5) $1 \mathrm{ml}$ of incubation saline contained $55.51 \mathrm{mg}$ atoms ${ }^{1} \mathrm{H}$ or ${ }^{3} \mathrm{H}$ at $2{ }^{\circ} \mathrm{C}$.

The conversion of observed median incorporation rates to estimated lipid synsthesis rates is thus:

$$
\begin{gathered}
S=d \times 24 \times 10 \times 55.51 \times 807.35 \times 10^{3} / \\
13.3 \times 3 \times 0.5 \times D
\end{gathered}
$$

or

$$
S=\left(1.076 .10^{10}\right) \cdot d / 19.95 \cdot D
$$

where $S=$ lipid (in $\mu$ g) synthesised $\mathrm{mg}^{-1}$ protein $10^{-1} \mathrm{~d}$; $d=\mathrm{dpm}{ }^{3} \mathrm{H}$ incorporated into total lipid $\mathrm{mg}^{-1}$ protein $\mathrm{h}^{-1}$ (corrected for no-tritium blanks); $D=$ specific activity of the incubation medium in $\mathrm{dpm} \mathrm{ml} \mathrm{ml}^{-1}$.

\section{Desaturase Activity}

Desaturase activity was assayed by monitoring the desaturation of palmitic acid in a cell-free system modified from that of Sargent et al. (1974) and Sargent and Lee (1975). Hepatopancreas and ovary tissue isolated from shrimps caught on Dec 31st, Jan 14th and Jan 29 th were extracted into $0.7 \mathrm{ml}$ of $0.25 \mathrm{M}$ sucrose in $0.1 \mathrm{M}$ Tris-HCl buffer adjusted to $\mathrm{pH} 7.4$ at $+2{ }^{\circ} \mathrm{C}$, using a teflon-glass homogeniser. Crude cell-free supernatants were prepared by centrifuging at $7,380 \times g_{a v}$ for $15 \mathrm{~min}$ at $+2^{\circ} \mathrm{C}$. Duplicate $100 \mu \mathrm{l}$ aliquots were then incubated for $5 \mathrm{~h}$ at $+2{ }^{\circ} \mathrm{C}$ in $0.9 \mathrm{ml}$ 
medium containing (final concentration) $10 \mathrm{mM}$ ATP $2.5 \mathrm{mM}$ NADPH, $2.5 \mathrm{mM}$ reduced glutathione, $0.8 \mathrm{mM}$ CoA, $25 \mathrm{mM}$ DL- $\alpha$-glycerophosphate and $10 \mathrm{mM}$ $\mathrm{MgCl}_{2}$ in $0.1 \mathrm{M}$ Tris- $\mathrm{HCl}$ buffer adjusted to $\mathrm{pH} 7.4$ at $+2{ }^{\circ} \mathrm{C}$. Incubation was started by the addition of $5 \mu \mathrm{Ci}$ $1-{ }^{14} \mathrm{C}$-palmitic acid in $20 \mu \mathrm{l}$ ethanol, and stopped by lipid extraction. Lipids were saponified and saturated and unsaturated fatty acids isolated by TLC on glassfibre papers impregnated with silica gel and $\mathrm{AgNO}_{3}$ (Graff et al., 1969).

\section{Chemical Assays}

Lipids were extracted and analysed by TLC as previously described (Clarke, 1979b). Protein in $\mathrm{NaOH}$ extracts of whole tissue or in $100 \mu \mathrm{l}$ aliquots of homogenates was assayed according to Hartree's (1972) modification of the Lowry method. Bovine serum albumin was used as standard, and corrections were applied for the presence of sucrose and Tris- $\mathrm{HCl}$ in the cell-free homogenates.

Scintillation fluids were from Packard, radiochemicals from Amersham International and all biochemicals from Sigma.

\section{Data Handling}

All calibration curves contained at least 8 points and were fitted by least squares regression. Statistical calculations were performed using either SPSS (subprograms Scattergram, Regression, Nonpar Corr, Oneway, Frequencies) or a Maximum Likelihood Program Statistical Package, MLP (Ross, 1980).

\section{RESULTS}

\section{Reproductive Biology}

Chorismus antarcticus is a protandrous (that is, sequential) hermaphrodite, and mature females breed seasonally. In many polar marine invertebrates vitellogenesis takes a year or even longer, but female $C$. antarcticus in winter show no sign of ovarian tissue. Although small ovaries are usually visible by September, the major increase in ovary size occurs during the final two or three months before spawning, which usually is in January. Females then brood the eggs over winter, and larvae hatch the following spring (Clarke, 1977a).

During the austral summer $1979 / 80$ ovary size increased linearly in December and January (Fig. 1).

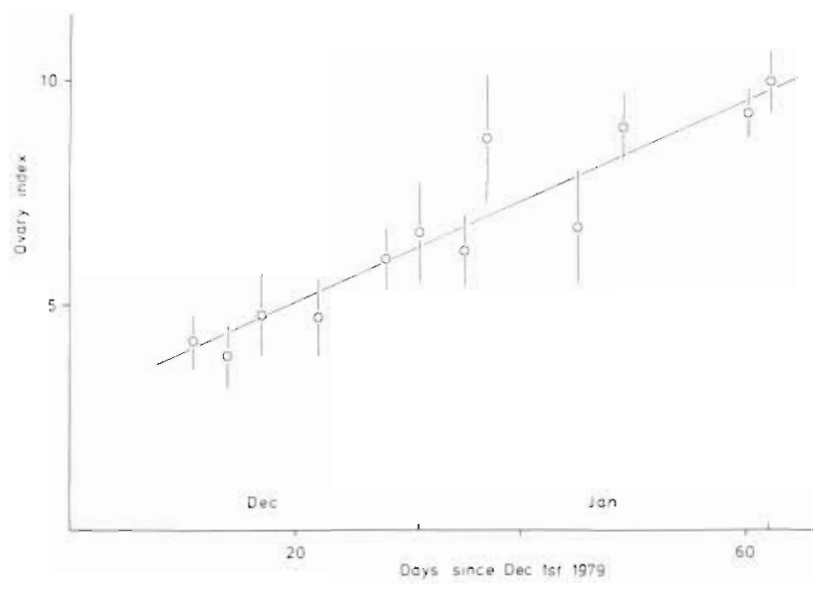

Fig. 1. Chorismus antarcticus. Increase in ovary index of maturing females with time during pre-spawning summer. Ovigerous and spent females excluded. Data shown are mean and standard deviation. Least square regression for individual females: $y_{i}=(0.1108 \pm 0.017) x_{i}+2.83 ; \quad \mathrm{n}=88$ $\mathrm{r}^{2}=0.33$

The rate of increase in ovary index, 0.1108 per day, was not significantly different from that observed in 1973/ $74(\mathrm{P}>0.05)$, although the timing of maturation was different in the 2 years (Table 1). From early January onwards samples contained an increasing proportion of ovigerous and spent females, the latter being shrimps that had spawned but which were not carrying eggs. The mean spawning date was 20th January, and differences in the timing of maturation in individual females account for the variance in ovary development visible in Fig. 1.

Very few egg counts were made in $1979 / 80$, but a comparison of those counts that were made with data for $1973 / 74$ and $1978 / 79$ shows that brood size varies from year to year. Comparison of the least squares regression of brood size on female fresh weight for the $3 \mathrm{yr}$ shows that the lines are parallel $(F=1.97$, $\mathrm{P}>0.05)$, but that the intercepts are significantly different $(F=3.35, P<0.05)$. This suggests that factors such as food availability or quality vary from season to season and that this affects the number of eggs a given size female can produce, but does so approximately equally for all sizes of female. The extent of this variation from year to year is small (Fig. 2; Table 1), and does not affect the comparison of annual individual reproductive effort with more temperate water species in Clarke (1979a).

\section{Lipid Accumulation in the Ovary}

There was no indication of any significant variation in the lipid content of the ovary as \% fresh weight during the sampling period (one-way analysis of vari- 
Table 1 Chorismus antarcticus. Statistical analyses of biological data. Day no is number of days since Dec 1st (in 1979/80) or Sept 1st (in 1973/74)

\begin{tabular}{|c|c|c|c|c|c|c|c|c|}
\hline $\begin{array}{l}\text { Dependant } \\
\text { variable }\end{array}$ & $\begin{array}{c}\text { Independant } \\
\text { variable }\end{array}$ & Date & $b$ & c & seb & $\mathrm{n}$ & $r^{2}$ & $\mathrm{~F}$ \\
\hline \multicolumn{9}{|l|}{ Females } \\
\hline Brood size & Fresh wt $(g)$ & $1973 / 74$ & 85.69 & -1.92 & 11.92 & 30 & 0.64 & 51.72 \\
\hline Brood size & Fresh wt (g) & $1978 / 79$ & 56.37 & 31.46 & 8.93 & 76 & 0.34 & 39.82 \\
\hline Brood size & Fresh wt $(g)$ & $1979 / 80$ & 43.06 & 62.57 & 42.57 & 5 & 0.01 & 1.02 \\
\hline Ovary index & Day no & $1973 / 74$ & 0.1103 & -1.10 & 0.012 & 34 & 0.72 & 80.65 \\
\hline Ovary index & Day no & $1979 / 80$ & 0.1108 & 2.83 & 0.017 & 88 & 0.33 & 42.15 \\
\hline $\begin{array}{l}\text { Ovary protein } \\
\text { (as \% Fresh wt) }\end{array}$ & Day no & $1979 / 80$ & 0.2301 & 22.42 & 0.067 & 19 & 0.41 & 12.03 \\
\hline Hepatopancreas Index & Day no* & $1973 / 74$ & -0.198 & 35.43 & 0.038 & 12 & 0.73 & 27.58 \\
\hline Hepatopancreas Index & Day no* & $1979 / 80$ & -0.083 & 9.17 & 0.029 & 27 & 0.25 & 8.16 \\
\hline \multicolumn{9}{|l|}{ Males } \\
\hline Hepatopancreas Index & Day no & $1979 / 80$ & 0.010 & 4.04 & 0.004 & 95 & 0.06 & 5.72 \\
\hline
\end{tabular}

Table 2. Chorismus antarcticus. Size and composition of hepatopancreas and ovary. South Georgia, 1979/80. All data are mean \pm standard error with number of individuals in parentheses

\begin{tabular}{|c|c|c|c|c|}
\hline Organ & Sex & Organ index & $\begin{array}{c}\text { Lipid } \\
\text { (\% fresh weight) }\end{array}$ & $\begin{array}{c}\text { Protein } \\
\text { (\% fresh weight) }\end{array}$ \\
\hline Hepatopancreas & male & $4.335 \pm 0.071 \quad(95)$ & $28.42 \pm 1.41$ & $13.06 \pm 0.29$ \\
\hline Ovary & maturing female & - & $17.53 \pm 0.61$ & - \\
\hline Hepatopancreas & maturing female & $5.501 \pm 0.137$ & $13.43 \pm 0.94 \quad(15)$ & $13.05 \pm 0.47(20)$ \\
\hline Hepatopancreas & ovigerous female & $4.985 \pm 0.212(16)$ & - & 11.98 \\
\hline Hepatopancreas & spent female & - & - & 11.42 \\
\hline
\end{tabular}

ance, $\mathrm{F}=2.44, \mathrm{P}>0.10)$. A mean value was therefore estimated (Table 2), and this allowed calculation of the mean rate of accumulation of lipid in the ovary of a female shrimp weighing $2 \mathrm{~g}$ (fresh weight) on 20th December as $3.70 \pm 0.08$ per $10 \mathrm{~d}$ (Table 3 ).

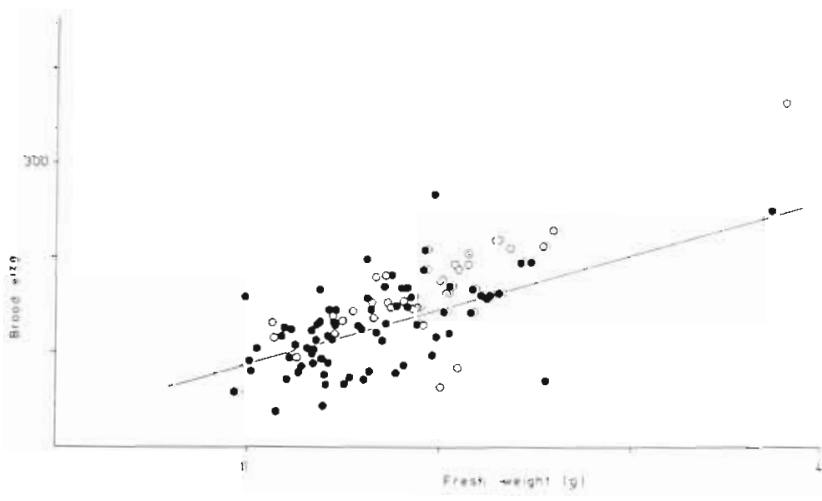

Fig. 2. Chorismus antarcticus. Relationship between number of eggs brooded and female fresh weight. (o) Data for 1973/ $74 ;(\bullet)$ Data for $1979 / 80$, with fitted least squares regression line. Statistical data given in Table 1
During the early stages of ovarian maturation there was no decrease in either the relative size or lipid content of the female hepatopancreas. Reserves were, however, mobilised from the hepatopancreas in the last 2 to $3 \mathrm{wk}$ before spawning, when there was a steady decline in hepatopancreas size (Fig. 3). In 1979/ 80 the loss of lipid from the hepatopancreas was $2.20 \pm 0.15 \mathrm{mg}$ per $10 \mathrm{~d}$ for a $2 \mathrm{~g}$ female, obviously insufficient to supply all the demands of the developing ovary. This conclusion is opposite from Clarke (1977a), which was based on data for $1973 / 74$ when the rate of decrease in hepatopancreas index was greater $(\mathrm{P}<0.05$, Table 1$)$ by a factor of more than twofold.

\section{Lipid Synthesis in vitro}

Because whole excised organs were incubated it was not possible to investigate the kinetics of ${ }^{3} \mathrm{H}$ incorporation into lipid with replicates from a single preparation. Instead whole hepatopancreas from a series of ovigerous females of a narrow size range were used. It 
Table 3. Chorismus antarcticus. Changes in total lipid contend of ovary and hepatopancreas. All calculations based on data in Tables 1 and 2, and referred to a maturing female of $2 \mathrm{~g}$ on Dec 20th (Day 20). All weights in $\mathrm{mg}$

\begin{tabular}{|c|c|c|c|c|c|}
\hline Lipid a & $\begin{array}{c}\text { dlation in or } \\
\text { Day } 20 \\
\text { (Dec 20th) }\end{array}$ & $\begin{array}{l}\text { Day } 30 \\
\text { (Dec 30th) }\end{array}$ & Lipid loss fr & $\begin{array}{l}\text { hepatopan } \\
\text { Day } 50 \\
\text { (Jan 19th) }\end{array}$ & $\begin{array}{l}\text { Day } 60 \\
\text { (Jan } 29 \text { th) }\end{array}$ \\
\hline Ovary index & 5.050 & 6.158 & Hepatopancreas index & 5.014 & 4.1826 \\
\hline $\begin{array}{l}\text { Fresh weight shrimp - } \\
\text { ovary }\end{array}$ & 1903.86 & 1903.86 & $\begin{array}{l}\text { Fresh weight shrimp - } \\
\text { ovary \& hepatopancreas }\end{array}$ & 1799.13 & 1799.13 \\
\hline Ovary fresh weight & 96.14 & 117.24 & Hepatopancreas weight & 94.97 & 78.54 \\
\hline Ovary lipid & 16.85 & 20.55 & Hepatopancreas lipid & 12.75 & 10.55 \\
\hline Ovary protein & 25.99 & 34.41 & & & \\
\hline \multicolumn{3}{|c|}{ Increase in lipid: $3.70 \mathrm{mg}$ per $10 \mathrm{~d}$} & \multicolumn{3}{|c|}{ Decrease in hepatopancreas lipid: $2.20 \mathrm{mg}$ per 10 days } \\
\hline \multirow{2}{*}{\multicolumn{3}{|c|}{$\begin{array}{l}\text { Standard error of this estimate: } 0.08(n=102) \\
\text { Mean protein content: } 30.20 \mathrm{mg}\end{array}$}} & Standard error of this estin & $0.15(n=$ & \\
\hline & & & & & \\
\hline \multicolumn{6}{|c|}{ These 2 estimates are significantly different $(t=9.53, P<0.001)$} \\
\hline
\end{tabular}

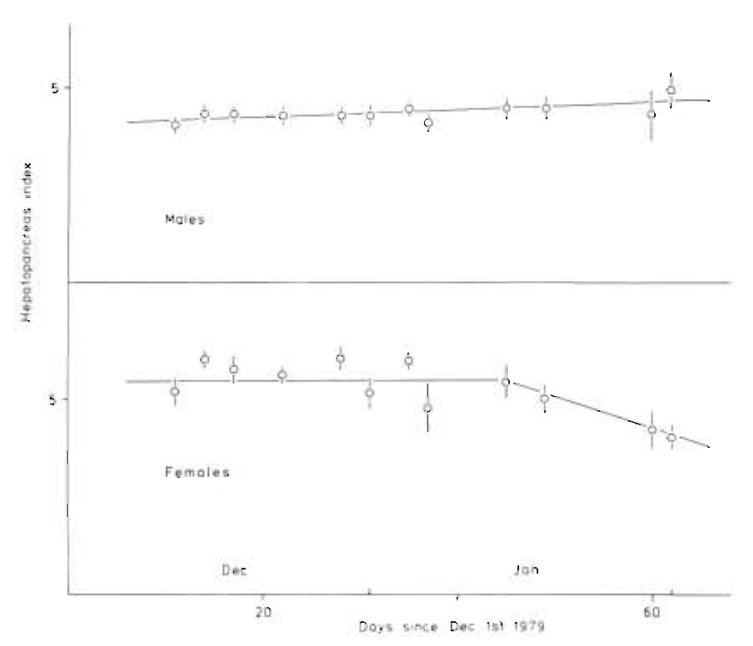

Fig. 3. Chorismus antarcticus. Variation in hepatopancreas index during summer for males and females with maturing ovaries. Data show mean and standard deviation. For males, fitted least squares regression coefficient was only just significantly different from $O(F=5.72, n=95)$. For maturing females, slope between Days 40 and 65 fitted by least squares regression as: $y_{1}=(-0.083 \pm 0.029) x_{1}+9.17 ; \quad \mathrm{n}=27$; $\mathrm{r}^{2}=0.25$. Least squares regression coefficient for Days 0 to 40 was not significantly different from $O(P>0.05, n=63)$

was expected that as these shrimps had spawned and were not moulting, lipid synthesis would be similar in all individuals and would approximate to basal lipid synthesis. However, this was not the case.

When the data for ovigerous females were corrected for incubation time they fell into 2 distinct groups: a close low group, and 3 shrimps with high synthesis rates (Fig. 4). Plotting only the low group data indicated a linear uptake of ${ }^{3} \mathrm{H}$ into lipid over a $5 \mathrm{~h}$ incubation time at $+2{ }^{\circ} \mathrm{C}$ (Fig. 5). On this basis it was assumed that in any one sample of shrimps a small number of individuals will show a high rate of lipid synthesis, but that for all shrimps uptake of ${ }^{3} \mathrm{H}$ was linear for $5 \mathrm{~h}$ in the incubation system used.
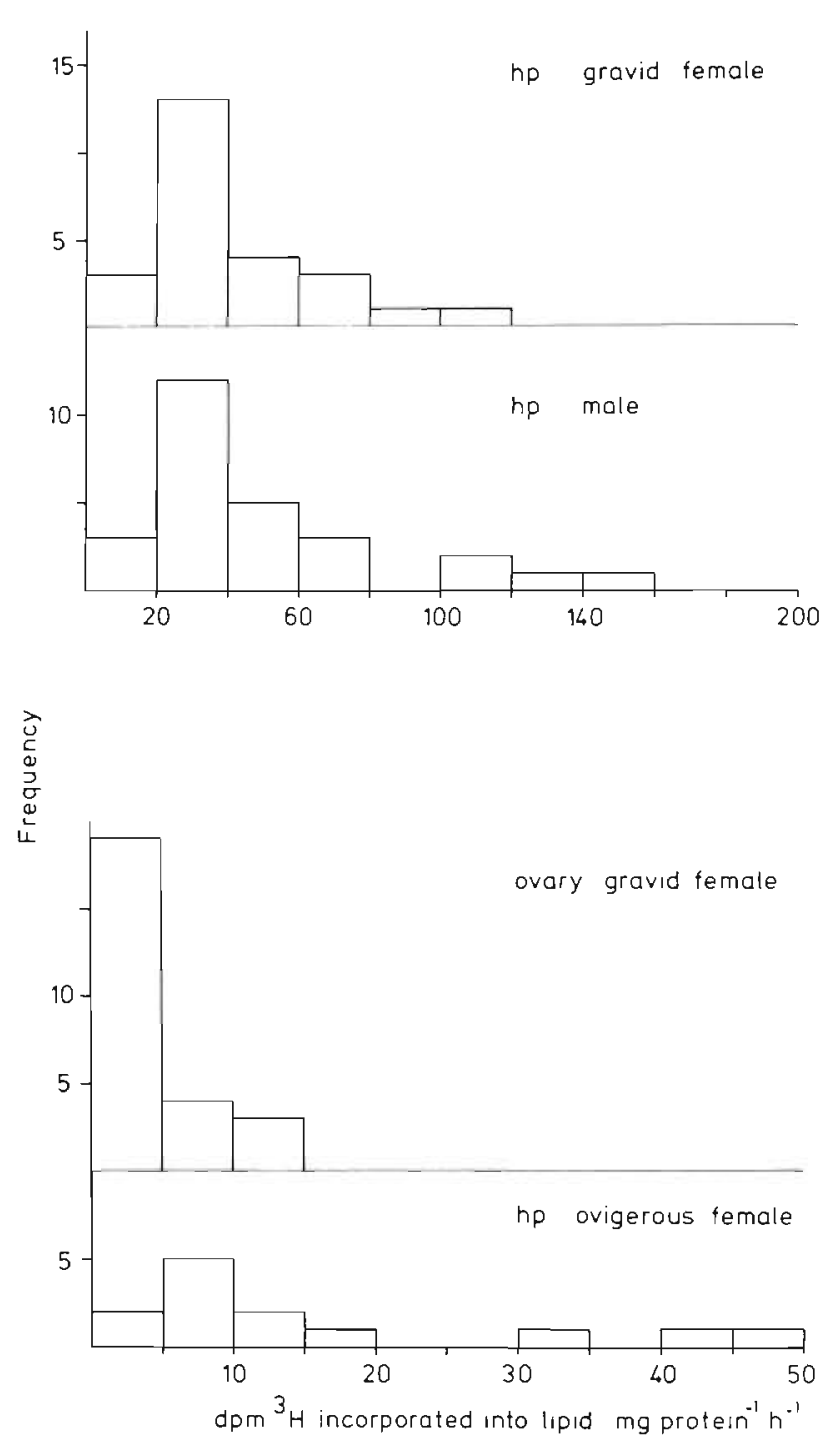

Fig. 4. Chorismus antarcticus. Frequency histograms of tritium incorporation into total lipid of hepatopancreas and ovary. Note different horizontal scales 


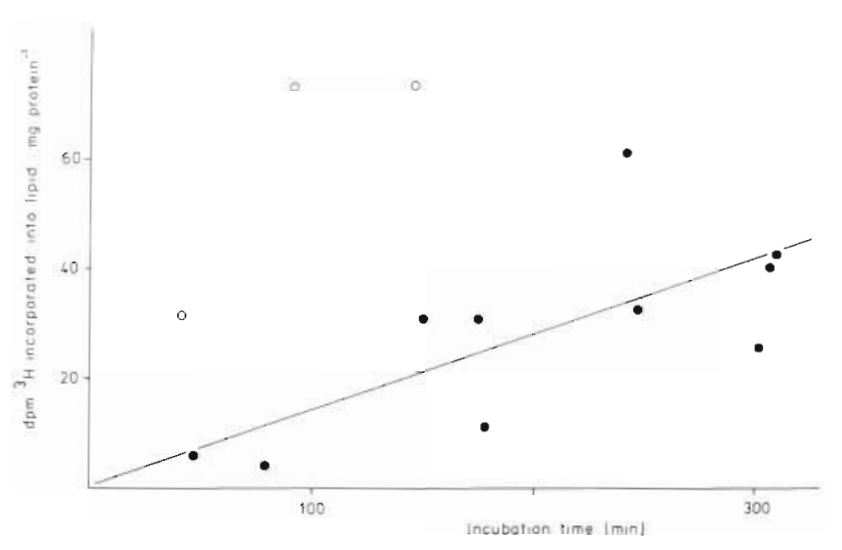

Fig. 5. Chorismus antarcticus. Time course of incorporation of tritium from crustacean saline into total lipid in hepatopancreas from 13 individual ovigerous females (i.e. females brooding eggs, but without developing ovaries). (0) high group females (incorporation $>30 \mathrm{dpm} \mathrm{mg}$ protein ${ }^{-1} \mathrm{~h}^{-1}$ ). Least squares regression for uptake by low group females: $y_{i}=0.1372 x_{1}+0.6421 ; \mathrm{n}=10 ; \mathrm{r}^{2}=0.51$

Ovaries and hepatopancreas from both females and males showed a wide range of lipid synthesis rates (Fig. 4). However, in neither males nor females was there any significant correlation between hepatopancreas synthesis rate and either hepatopancreas index or date (Spearmann rank correlation, all $\mathrm{P}>0.05$ ). In maturing ovaries there was a significant variation in lipid synthesis rate between samples taken on different days (one way analysis of variance, $F=3.91$, $\mathrm{P}=0.016$ ), but there was no significant systematic correlation with either date or ovary index (Spearmann rank correlation, both $\mathrm{P}>0.05$ ). The same pattern was evident in the male hepatopancreas synthesis rates, namely a marked sample to sample variation $(F=2.67, P=0.058)$ but no systematic correlation with either date or organ index. It is possible that sample to sample variation in synthesis rates reflects a diurnal, tidal or some other periodic cycle in the feed- ing activity of the shrimps. This is supported by a highly significant correlation between hepatopancreas and ovary synthesis rates in female shrimps (Spearmann $I_{s}=0.632, P=0.001$ ). Since no significant systematic trends in synthesis rates with either organ index or date could be detected, all data were pooled (Fig. 4). Frequency distributions were, however, often markedly skewed and so median rather than mean values have been used in all calculations.

Despite the wide range of lipid synthesis rates observed in the various tissues, it is possible to draw some valid conclusions. Lipid synthesis was high in the hepatopancreas of females with maturing ovaries, and the ovaries themselves also showed some synthetic activity. In ovigerous females i.e. females that had spawned and were carrying eggs on the pleopods), synthesis rates were lower, and presumably represented the basal lipid turnover necessary for day to day living. Males, which probably have a limited energetic demand for breeding (Clarke, 1977a) and are moulting at this time (Clarke and Lakhani, 1979), had a very wide spread of lipid synthesis rates. This is probably because any one sample will have contained males at all stages of the moult cycle, and lipid synthesis has been shown to vary with cycle stage (Kanazawa and Teshima, 1977).

The calculation of absolute rates of lipid synthesis from the observed rate of ${ }^{3} \mathrm{H}$ incorporation is based on a number of assumptions (see Materials and Methods). Nevertheless it is useful to perform the calculation to derive at least an order of magnitude figure. The rates of lipid synthesis calculated from the observed ${ }^{3} \mathrm{H}$ incorporation rates are shown in Table 4. Assuming that the value for an ovigerous female represents basal turnover, then the excess lipid synthesis associated with egg production in a maturing female is $(195.48+37.78)-36.48=196.78 \mu \mathrm{g}$ lipid per $10 \mathrm{~d}$ for a shrimp of $2 \mathrm{~g}$ fresh weight. This is about 15 times

Table 4. Chorismus antarcticus. Estimated lipid synthesis rates calculated from median observed incorporation rates of tritium into lipid of isolated tissues. Data calculated for a maturing female of $2 \mathrm{~g}$ fresh weight on Day 20 (Dec. 20th)

\begin{tabular}{|c|c|c|c|c|c|}
\hline & $\begin{array}{l}\mathrm{dpm}{ }^{3} \mathrm{H} \\
\text { incorporated into } \\
\text { lipid } \mathrm{h}^{-1} \mathrm{mg} \\
\text { protein (median) }\end{array}$ & $\mathrm{n}$ & $\begin{array}{c}\mu g \text { lipid } \\
\text { synthesised } \\
10 d^{-1} \mathrm{mg} \\
\text { protein }{ }^{-1}\end{array}$ & $\begin{array}{l}\text { mg protein } \\
\text { in tissue } \\
\text { for } 2-\mathrm{g} \text { shrimp }\end{array}$ & $\begin{array}{c}\text { ug lipid } \\
\text { synthesised } \\
10 \mathrm{~d}^{-1} 2-\mathrm{g} \text { shrimp }\end{array}$ \\
\hline \multicolumn{6}{|l|}{ Maturing female } \\
\hline Hepatopancreas & 36.170 & 26 & 13.52 & 14.46 & 195.48 \\
\hline Ovary & 3.348 & 26 & 1.25 & 30.20 & 37.78 \\
\hline \multicolumn{6}{|l|}{ Ovigerous female } \\
\hline Hepatopancreas & 8.351 & 13 & 3.12 & 11.69 & 36.48 \\
\hline \multicolumn{6}{|l|}{ Male } \\
\hline Hepatopancreas & 32.118 & 27 & 12.00 & - & - \\
\hline
\end{tabular}


too low to account for the observed rate of lipid accumulation in the ovary $(3.70 \pm 0.08 \mathrm{mg}$ per $10 \mathrm{~d})$, suggesting that most of the yolk lipid is derived directly from the food.

\section{Incorporation of Tritium into Phospholipids}

In the above calculation it was assumed that all the lipid synthesised was triacylglycerol (see Materials and Methods). Since $42 \%$ of egg lipid in Chorismus antarcticus is phospholipid (Clarke, 1977b), this is unlikely to be so. A number of lipid samples were therefore separated into lipid classes by TLC and the phospholipid (PL) and triacylglycerol (TAG) fractions counted individually. The mean sum total of counts in the PL and TAG fractions combined was not significantly different from that measured in total lipid (Student's $t, P>0.05$ ). Crustaceans are incapable of synthesising sterols de novo (Walton and Pennock, 1972; Goad, 1976) and all other lipid synthesis was assumed to be negligible. The counts in PL and TAG fractions were therefore expressed as a percentage of the counts observed in both fractions combined (Table 5).

Table 5. Chorismus antarcticus. Incorporation of tritium into phospholipid and triacylglycerol from tissues of maturing female and male. Mean \pm standard error

\begin{tabular}{|lccc|}
\cline { 3 - 4 } & $\mathrm{n}$ & $\begin{array}{c}\% \text { total } \\
\text { counts in } \\
\text { phospholipid }\end{array}$ & $\begin{array}{c}\% \text { total } \\
\text { counts in } \\
\text { triacylglycerol }\end{array}$ \\
\hline $\begin{array}{l}\text { Maturing female } \\
\text { Hepatopancreas }\end{array}$ & 10 & $63.95 \pm 2.11$ & $36.05 \pm 2.11$ \\
$\quad$ Ovary & 10 & $55.12 \pm 1.90$ & $44.88 \pm 1.90$ \\
$\begin{array}{l}\text { Male } \\
\text { Hepatopancreas }\end{array}$ & 10 & $54.35 \pm 1.35$ & $45.65 \pm 1.35$ \\
\hline
\end{tabular}

These results demonstrate substantial phospholipid synthesis in both hepatopancreas and ovary. Also the proportion of newly synthesised fatty acid stored as phospholipid is greater in maturing female hepatopancreas than in male hepatopancreas $(\mathrm{P}<0.05$ after arcsine transformation).

\section{Desaturase Activity}

Desaturation of $1-{ }^{14} \mathrm{C}$-palmitic acid was detected in all tissues examined (Table 6). Because this was an in vitro assay using a cell-free homogenate, it was impossible to relate the data to whole animal activity. Nonetheless the data do show that activity was greater in hepatopancreas than ovary in maturing females (Mann-Whitney $U$ test, $\mathrm{P}<0.05$ ), as with the lipid
Table 6. Chorismus antarcticus. Palmitoyl-CoA desaturase activites in cell-free homogenates of tissues from maturing females and males

\begin{tabular}{|c|c|c|c|}
\hline & Median & n & Range observed \\
\hline \multicolumn{4}{|l|}{ Maturing female } \\
\hline Ovary & 0.862 & 6 & $0.144-1.616$ \\
\hline Hepatopancreas & 5.400 & 7 & $1.160-37.940$ \\
\hline \multicolumn{4}{|l|}{ Male } \\
\hline Hepatopancreas & & 2 & $4.377,91.695$ \\
\hline
\end{tabular}

synthesis data. In both female and male hepatopancreas incubations there were single very high desaturase results. Data were too few to test for any correlation with date or organ index.

\section{Lipid Synthesis in Brooded Eggs}

When first spawned each egg contains about $125 \mu \mathrm{g}$ lipid $(6.6 \%$ fresh $w \mathrm{t})$, and this increases to $\sim 230 \mu \mathrm{g}$ during the early stages of embryonic development (Clarke, 1977a). This somewhat surprising result indicates lipid synthesis within the egg during brooding, although from what source is not clear. An increase in egg lipid content during early embryonic development also occurs in the amphipod Pontogeneia antarctica (Richardson, 1977). During the final 6 mo of development in $C$. antarcticus eggs, lipid is utilised at a mean rate of $676 \mathrm{ng} \mathrm{egg}{ }^{-1} \mathrm{~d}^{-1}$ (Clarke, 1977a).

A preliminary incubation of newly spawned eggs in seawater containing $0.65 \mathrm{mCi} / \mathrm{ml}^{3} \mathrm{H}_{2} \mathrm{O}$ and $2.5 \mu \mathrm{Ci} / \mathrm{ml}$ $\mathrm{Na}\left[\mathrm{U}-{ }^{14} \mathrm{C}\right]$ acetate $\left(58 \mathrm{mCi} \mathrm{mmole}^{-1}\right)$ revealed active lipid synthesis, albeit slow, and suggests uptake of small molecules from seawater as a possible source of lipid precursors (Table 7).

Table 7. Chorismus antarcticus. Uptake of ${ }^{3} \mathrm{H}_{2} \mathrm{O}$ and $\mathrm{Na}$ $\left[\mathrm{U}-{ }^{14} \mathrm{C}\right.$ ] acetate from seawater by newly-spawned eggs

\begin{tabular}{|c|c|c|c|c|c|}
\hline \multirow[t]{2}{*}{$\begin{array}{c}\text { No. of } \\
\text { eggs }\end{array}$} & \multirow{2}{*}{$\begin{array}{l}\text { Incuba- } \\
\text { tion time } \\
\text { (min) }\end{array}$} & \multicolumn{2}{|c|}{$\begin{array}{c}\Sigma \mathrm{dpm} \\
\text { incorporated }\end{array}$} & \multicolumn{2}{|c|}{$\begin{array}{c}\text { dpm incorporated } \\
\text { egg }^{-1} \mathrm{~h}^{-1}\end{array}$} \\
\hline & & $3_{\mathrm{H}}$ & $14_{C}$ & $3_{H}\left(\times 10^{3}\right)$ & $14_{C}$ \\
\hline 74 & 315 & 315 & 9164 & 810.8 & 23.6 \\
\hline 64 & 315 & 228 & 7175 & 678.6 & 21.4 \\
\hline
\end{tabular}

\section{DISCUSSION}

It is not always easy to say anything useful about the lipid metabolism of a whole animal based solely on measurements in vitro of isolated organs incubated in 
artificial media. However, in small shrimps such as Chorismus antarcticus, in vivo work is not possible with ${ }^{3} \mathrm{H}_{2} \mathrm{O}$, and so assay in vitro is the only approach available. In the experiments undertaken here, organs from males, females with maturing ovaries, and ovigerous females were compared under identical conditions, and the observed tritium uptakes indicate clearly that maturation of the ovary involves an increase in lipid synthesis, albeit small. This agrees with compositional studies which have suggested that at least some of the fatty acids in decapod eggs are synthesised de novo by the maturing female (Morris, 1973; Clarke, 1977b, 1979b).

Similar studies in vitro of isolated hepatopancreas from Thysanoessa inermis have shown that a $50 \mathrm{mg}$ euphausiid is capable of synthesising de novo about $0.1 \mathrm{mg}$ fatty acid $\mathrm{d}^{-1}$ at $5^{\circ} \mathrm{C}$. This is a much greater synthetic rate than measured in Chorismus antarcticus (by over 2 orders of magnitude), and comparable to the observed rate of increase in the total lipid of euphausiids during early summer (Falk-Petersen et al., 1981; Henderson et al., 1981). This result for $T$. inermis suggests that valid comparisons between in vitro and in vivo measurements can be made, and that the low level of synthetic activity observed in $C$. antarcticus is real.

It is clear from laboratory feeding studies that decapods cannot produce polyenoic fatty acids de novo (see, for example, Kanazawa et al., 1979). Futhermore, they appear to have only a limited capacity for producing these essential fatty acids by chain elongation and desaturation of precursors such as $18: 3 \omega 3$ and $18: 3 \omega 6$ (Colvin, 1976; Guary et al., 1976). Chorismus antarcticus will thus need to obtain almost all of its polyenoic fatty acids pre-formed from the diet, and in particular females will need substantial quantities during vitellogenesis (Clarke and Wickins, 1980; Middleditch et al., 1980). The hepatopancreas at the beginning of vitellogenesis contains only a small fraction of the lipid necessary for the eggs (Table 2), and this store remains constant in size for much of ovarian development, so mobilisation of previously stored essential fatty acids does not appear to be significant

The eggs of Chorismus antarcticus are rich in polyenoic fatty acids ( $44.7 \%$ total fatty acids in egg PL, and $46.7 \%$ in egg TAG: Clarke, 1977b). Approximately $45 \%$ of the total fatty acids required for vitellogenesis must therefore come straight from the food. Assuming that in the late stages of vitellogenesis some hepatopancreas lipid reserves are also mobilised to provide egg lipid, it is clear that the maximum requirement for de novo lipid synthesis is small. Since any food lipid utilised for polyenoic fatty acids will also contain plenty of saturated and monoenoic fatty acids, and the hepatopancreas remains constant in size throughout most of the period of vitellogenesis, it would appear that the hepatopancreas is acting more as a metabolic centre modifying incoming lipid than a source of yolk in itself.

What seems to be happening in Chorismus antarcticus is that in summer, when food is plentiful for much of the Antarctic benthos (Clarke, 1980a), gonad maturation is sufficiently slow for most of the energetic requirements to be met directly from the food. Polyenoic fatty acids are accumulated from the diet, and the hepatopancreas is active in producing the fatty acid spectrum necessary for the yolk. In particular there may be active synthesis of $16: 0,16: 1 \omega 7$ and $18: 1 \omega 9$, activity which would be measurable as tritium uptake from crustacean saline. The hepatopancreas lipids, although relatively constant in amount, are thus in a state of flux, with food lipids being absorbed and egg lipids produced.

The accumulation of egg lipid alters the overall lipid composition of the maturing female shrimp. In shrimps which are not undergoing vitellogenesis, variations in total lipid are largely caused by changes in TAG content. In females accumulating ovarian lipid, both PL and TAG are stored (Clarke, 1977b, 1979b).

The decrease in hepatopancreas reserves in the last few weeks before spawning may indicate a cessation of feeding, possibly associated with the pre-spawning moult. At this time both hepatopancreas and ovary lipid synthesis rates were lower, although not significantly so. The rate of decrease in hepatopancreas index varies from year to year (Table 1) and, like the variations in brood size and the timing of spawning, may reflect annual fluctuations in food quality or quantity.

The almost complete dependence of Chorismus antarcticus on immediate food intake to supply egg lipid, coupled with only slight utilisation of hepatopancreas reserves and a low rate of de novo synthesis, is a very different energetic strategy from that of planktonic euphausiids, some benthic echinoderms, or even other decapods. In the marine prawn Parapenaeopsis hardwickii, for example, ovarian maturation is accompanied by a parallel decrease in hepatopancreas reserves (Kulkarni and Nagabhushanam, 1979).

In many cold water euphausiids ovarian maturation is also accompanied by a decrease in hepatopancreas stores (Ponomoreva, 1963; Littlepage, 1964), since vitellogenesis usually proceeds over winter when food is scarce or non existent. Spawning is in spring, and the newly hatched lavae can exploit the summer phytoplankton bloom. An exception to this general rule is the Antarctic krill Euphausia superba which spawns in late summer (Clarke, 1980b). The active lipid synthesis detected in Thysanoessa inemis during late May (Henderson et al., 1981), was in the period immediate- 
ly after spawning when lipid reserves were once more being accumulated (Falk-Petersen et al., 1981).

The pyloric caecum of sea stars performs many of the functions of the crustacean hepatopancreas, and the size of the caecae often decreases as the gonads mature (see the review by Lawrence and Lane, in press). This pattern is usually interpreted as indicating a transfer of resources to the gonads when food is scarce. The starfish Pisaster ochraceous, for example, feeds predominantly in summer and stores reserves in the pyloric caecae. In autumn the gonads start to mature and, since feeding activity is greatly reduced over winter, energy for vitellogenesis is provided mostly by these previously stored reserves. During winter there is a steady decrease in hepatic index, and a corresponding increase in gonad index, although the sum of the two remains approximately constant. Spawning occurs in June, by which time the starfish are feeding actively again and replenishing the pyloric caecal reserves (Mauzey, 1966). Lipid synthesis, measured in vitro as uptake of ${ }^{14} \mathrm{C}$-acetate and ${ }^{14} \mathrm{C}$-glucose by isolated tissues, was highest in the pyloric caecae in November when reserves were actively being stored, but then declined. Synthesis in the gonads was initially low, but increased to a maximum in February. This pattern matched well the variation in organ indices, although it is interesting that starvation reduced the gonad synthesis rates to a very low level, suggesting that maturation is not simply a transfer of reserves form store to gonad (Allen, 1964; Giese, 1966).

In omnivorous or scavenging species which do not suffer a seasonal shortage of food, this reciprocal relationship between the pyloric caecae and gonads is no longer seen. Examples are deposit feeders (Shick et al., 1981), some deep sea species and the Antarctic asteroid Odontaster validus (Pearse, 1965), a slowgrowing, scavenging species for which food is available year-round. In $O$. validus both pyloric caecae and gonads accumulate lipid when food in plentiful, the caecae acting as a buffer and supplying lipid to the slowly developing gonads whenever food is scarce (Pearse, 1965).

In Chorismus antarcticus food availability is almost certainly seasonal, since both somatic growth and vitellogenesis are confined to the summer months. Spawning occurs in mid to late summer, but this allows 5 mo for production of a mature ovary. The contrasting patterns of energy utilisation of the 2 Antarctic species C. antarcticus and Odontaster validus are thus explicable in terms of the pattern of food availability, rather than rate limitation by cold (Clarke, 1980a).

Acknowledgements. I am very grateful to Drs. J. R. Sargent and R. J. Henderson for valuable technical advice and for criticism of an early draft of this paper. I am also grateful to R. Forster and Dr. D. J. Morris for much help with sampling, not all of it under pleasant conditions.

\section{LITERATURE CITED}

Allen, W V (1964). Fat synthesis in the ochre star Pisaster ochraceus studied by radioactive tracers. Ph.D. thesis, Stanford University

Bligh, E. G., Dyer, W. J. (1959). A rapid method of total lipid extraction and purification. Can. J. Biochem. Physiol. 37: 911-917

Clarke, A. (1977a). Seasonal variations in the total lipid content of Chorismus antarcticus (Pfeffer) (Crustacea: Decapoda) at South Georgia. J. exp. mar. Biol. Ecol. 27: 93-106

Clarke, A. (1977b). Lipid class and fatty acid composition of Chorismus antarcticus (Pfeffer) (Crustacea: Decapoda) at South Georgia. J. exp. mar. Biol. Ecol. 28: 297-314

Clarke, A. (1979a). On living in cold water: $K$-strategies in Antarctic benthos. Mar. Biol. 55: 111-119

Clarke, A. (1979b). Lipid content and composition of the pink shrimp, Pandalus montagui (Leach) (Crustacea: Decapoda). J. exp. mar. Biol. Ecol. 38: 1-17

Clarke, A. (1980a). A reappraisal of the concept of metabolic cold adaptation in polar marine invertebrates. Biol. J. Linn. Soc. 14: 77-92

Clarke, A. (1980b). The biochemical composition of krill, Euphausia superba Dana, from South Georgia. J. exp. mar. Biol. Ecol. 43: 221-236

Clarke, A., Lakhani, K. H. (1979). Measures of biomass, moulting behaviour and the pattern of early growth in Chorismus antarcticus (Pfeffer). Br. Antarct. Surv. Bull. 48: $61-88$

Clarke, A., Wickins, J. F. (1980). Lipid content and composition of cultured Penaeus merguiensis fed with animal food. Aquaculture 20: 17-27

Colvin, P. M. (1976). The effect of selected seed oils on the fatty acid composition and growth of Penaeus indicus. Aquaculture 8: 81-89

Falk-Petersen, S., Gatten, R. R., Sargent, J. R., Hopkins, C. C. E. (1981). Ecological investigations on the zooplankton community in Balsfjorden, northern Norway: Seasonal changes in the lipid class composition of Meganyctiphanes norvegica, Thysanoessa raschii and Thysanoessa inermis. J. exp. mar. Biol. Ecol. 54: 209-224

Giese, A. C. (1966). Lipids in the economy of marine invertebrates. Physiol. Rev. 46: 244-298

Goad, L. J. (1976). The steroids of marine algae and invertebrate animals. In: Malins, D. C., Sargent, J. R. (eds.) Biochemical and biophysical perspectives in marine biology, Vol. 3. Academic Press, London, pp. 213-318

Graff, G., Marcel, Y. L., Holman, R. T. (1969). Analysis of labelled fatty acids by argentation chromatography of their methyl esters on glass fiber sheets. J. chromatogr. Sci. 7: 298-299

Guary, J. C., Kayama, M., Murakami, Y., Ceccaldi, H. J. (1976). The effects of a fat-free and compounded diets supplemented with various oils on moult, growth and fatty acid composition of prawn, Penaeus japonicus Bate. Aquaculture 7: 245-254

Hartree, E. E. (1972). Determination of protein: a modification of the Lowry method that gives a linear photometric response. Analyt. Biochem. 48: 122-127 
Henderson, R. J., Sargent, J. R., Falk-Petersen, S. (1981) Lipogenesis in the Arctic euphausiid Thysanoessa inermis. Mar. Biol. 63: 235-240

Jungas, R. L. (1968). Fatty acid synthesis in adipose tissue incubated in tritiated water. Biochemistry (Am. chem. Soc.), Easton, Pa. 7: 3708-3717

Kanazawa, A., Teshima, S. (1977). Biosynthesis of fatty acids from acetate in the prawn, Penaeus japonicus. Mem. Fac Fish., Kagoshima Univ. 26: 49-53

Kanazawa, A., Teshima, S., Tokiwa, S. (1979). Biosynthesis of fatty acids from palmitic acid in the prawn, Penaeus japonicus. Mem. Fac. Fish., Kagoshima Univ. 28: 17-20

Kulkami, G. K., Nagabhushanam, R. (1979). Mobilisation of organic reserves during ovarian development in a marine penaeid prawn, Parapenaeopsis hardwickii (Miers) (Crustacea, Decapoda, Penaeidae). Aquaculture 18: 373-377

Lawrence, J. M., Lane, J. E. M. (in press). The utilisation of nutrients by post-metamorphic echinoderms. In: Jangoux, M. Lawrence, J. M. (eds.) Echinoderm nutrition. Balema, Rotterdam

Littlepage, J. L. (1964), Seasonal variation in lipid content of two Antarctic marine Crustacea. In: Carrick, R., Holdgate, M., Prévost, J. (eds.) Biologie Antarctique. Hermann, Paris, pp. 463-470

Mauzey, K. P. (1966). Feeding behaviour and reproductive cycles in Pistaster ochraceus. Biol. Bull. mar. biol. Lab., Woods Hole 131: 127-144

Middleditch, B. S., Missler, S. R., Hines, H. B., McVey, J. P., Brown, A., Ward, D. E., Lawrence, A. L. (1980). Metabolic profiles of penaeid shrimp: Dietary lipids and ovarian maturation. J. Chromatog. 195: 359-368

Morris, R. J. (1973). Relationships between the sex and degree of maturity of marine crustaceans and their lipid compositions. J. mar. biol. Ass. U. K. 53: 27-37

Pearse, J. S. (1965). Reproductive periodicities in several contrasting populations of Odontaster validus Koehler, a common Antarctic asteroid. Antarct. Res. Ser. 5: 39-85
Ponomoreva, L. A. (1963). Evfauziidy severnio poloviny Tikhogo okeana, okh rasprostranenie: ekologiya massovykh vidiv, Izdatel'stvo Akademii Nauk S.S.S.R., Moskva [Translation: Euphausiids of the north Pacific, their distribution and ecology. Israel Program for Scientific Translations, Jerusalem, 1966]

Richardson, M. G. (1977). The ecology (including physiological aspects) of selected Antarctic marine invertebrates associated with inshore macrophytes. Ph.D. thesis, University of Durham

Ross, G. J. S. (1980). Maximum likelihood program, Rothamsted Experimental Station, U.K.

Sargent, J. R., Gatten, R. R., McIntosh, R. (1974). Biosynthesis of wax esters in cell-free preparations of Euchaeta norvegica. Comp. Biochem. Physiol. 47B: 217-227

Sargent, J. R., Lee, R. F. (1975). Biosynthesis of lipids in zooplankton from Saanich Inlet, British Columbia, Canada. Mar. Biol. 31: 15-23

Shick, J. M., Taylor, W. F., Lamb, A. N. (1981). Reproduction and genetic variation in the deposit-feeding sea star Ctenodiscus crispatus. Mar. Biol. 63: 51-66

Thorson, G. (1950). Reproductive and larval ecology of marine bottom invertebrates. Biol. Rev. 25: 1-45

Walton, M. J., Pennock, J. F. (1972). Some studies on the biosynthesis of ubiquinone, isoprenoid alcohols, squalene and sterols by marine invertebrates. Biochem. J. 127: $471-479$

Windmueller, H. G., Spaeth, A. E. (1966). Perfusion in situ with tritium oxide to measure hepatic lipogenesis and lipid secretion. J. biol. Chem. 241: 2891-2899

Zarenkov, N. A. (1970). Crustacean Decapoda collected by the Soviet Antarctic Expeditions in the Antarctic and antiboreal regions. In: Andriyashev, A. P., Ushakov, P. V. (eds.) Studies of marine fauna 6 (14): Biological reports of the Soviet Antarctic Expedition (1955-1958), Vol. 4. Israel Program for Scientific Translations, Jerusalem, pp. $153-201$ 